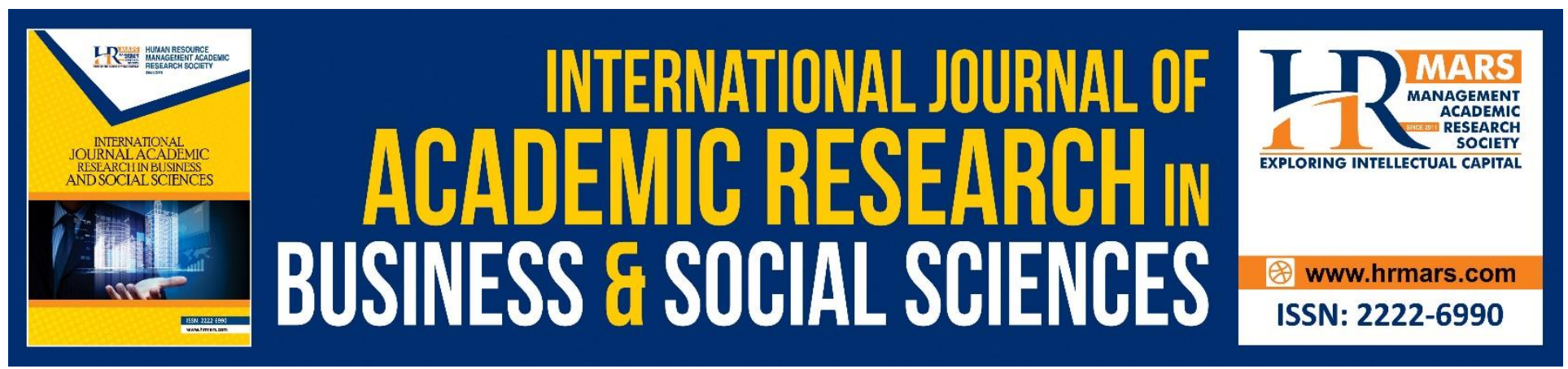

\title{
An Islamic Perspective of Child Weaning and Breast Feeding and its Implication towards Achieving Sustainable Development Goals
}

Badirudeen Abdulganiyu, Rabi'a Shehu Fodio, Safiya Ismail Kaita

To Link this Article: http://dx.doi.org/10.6007/IJARBSS/v8-i7/4414

DOI: $\quad 10.6007 /$ IJARBSS/v8-i7/4414

Received: 20 June 2018, Revised: 14 July 2018, Accepted: 28 July 2018

Published Online: 30 July 2018

In-Text Citation: (Abdulganiyu, Fodio, \& Kaita, 2018)

To Cite this Article: Abdulganiyu, B., Fodio, R. S., \& Kaita, S. I. (2018). An Islamic Perspective of Child Weaning and Breast Feeding and its Implication towards Achieving Sustainable Development Goals. International Journal of Academic Research in Business and Social Sciences, 8(7), 718-726.

Copyright: (c) 2018 The Author(s)

Published by Human Resource Management Academic Research Society (www.hrmars.com)

This article is published under the Creative Commons Attribution (CC BY 4.0) license. Anyone may reproduce, distribute, translate and create derivative works of this article (for both commercial and non-commercial purposes), subject to full attribution to the original publication and authors. The full terms of this license may be seen

at: http://creativecommons.org/licences/by/4.0/legalcode

Vol. 8, No. 7, July 2018, Pg. 718 - 726

http://hrmars.com/index.php/pages/detail/IJARBSS

JOURNAL HOMEPAGE

Full Terms \& Conditions of access and use can be found at http://hrmars.com/index.php/pages/detail/publication-ethics 


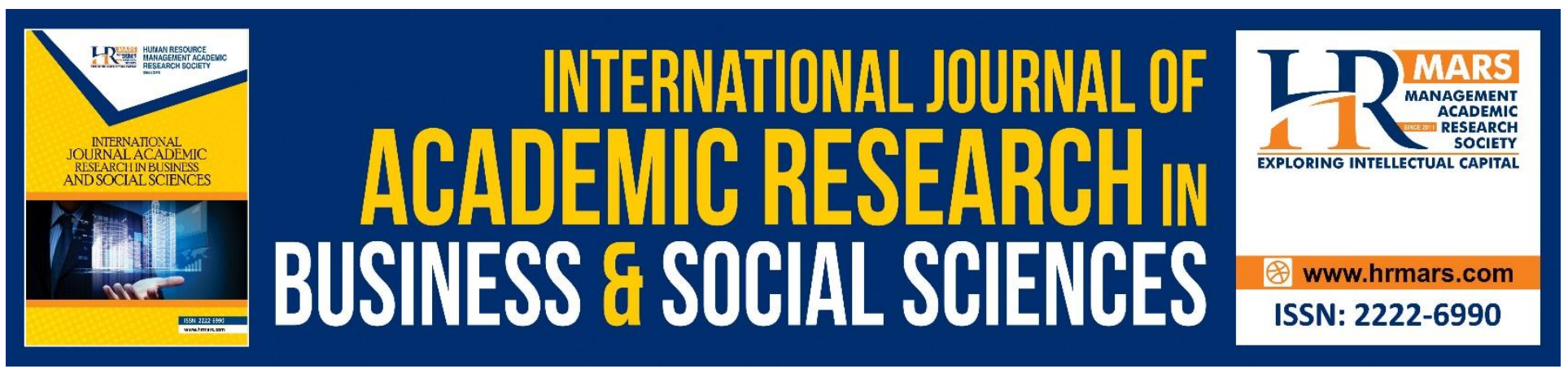

\title{
An Islamic Perspective of Child Weaning and Breast Feeding and its Implication towards Achieving Sustainable Development Goals
}

\author{
Badirudeen Abdulganiyu \\ Department of Islamic Studies, F.C.T College of Education Zuba-Abuja \\ Email: badirudeenabdulgaiyu088@gmail.com \\ Rabi'a Shehu Fodio \\ Department of Arabic and Islamic Studies, Sokoto State University, Sokoto \\ Email: fodiorabi@gmail.com \\ Safiya Ismail Kaita \\ Department of Islamic Studies, F.C.T. College of Education, Zuba
}

\begin{abstract}
Sustainable development is world proclamation, about the development of today without negative effect on development of young generation. It is all about proposing of a good standard living for every Human Being in the world. It aims at making every individual live conveniently, it is in this regard this paper accesses the child weaning and breast feeding and its implication in achieving sustainable development goals by 2030. Effort is made to discuss the concept of breast feeding and child weaning, conditions surrounding child weaning and breast feeding and its implications towards reducing mother-child mortality. The paper therefore concludes that if Muslims strictly follow the guideline of Shari'a definitely the goal of sustainable development of ensuring healthy lives and promote wellbeing for all at all age by 2030 would be achieved
\end{abstract}

Keywords: Sustainable Development, Breastfeeding and Weaning

\section{Introduction}

Children are the future of any given society and the right of every child in any given society among other things is the right to adequate care. For a child to grow and develop properly, he needs adequate breast feeding. Many children in contemporary society especially in third world suffer adequate caring. Numbers of these children suffer right from infant to the adulthood if not throughout their life span. Could this suffering be as a result of lack of poor condition of the parent? as it shown by the world record that "poor remain widespread in sub-Saharan Africa where 40 percent (\%) of the people lived on less than 1.90 US Dollar per day and 16 percent (16\%) of 
INTERNATIONAL JOURNAL OF ACADEMIC RESEARCH IN BUSINESS AND SOCIAL SCIENCES Vol. 8, No. 7, July 2018, E-ISSN: 2222-6990 @ 2018 HRMARS

unemployed youth were living below the poverty line" or could it be as a result of malnutrition emanated from the high cost of food production or insufficient means to adequately produce enough food for the family on the side of the fathers who are striving to sustain their family, when a nursing mother is not adequately feed, how will she adequately feed the new infant (United Nations, 2016)?. A well grown and developed child depend on adequate nutrition especially when the child is exposed to exclusive breast feeding, this is the parameter upon which Allah (SWT) placed breast feeding in the Qur'an thus:

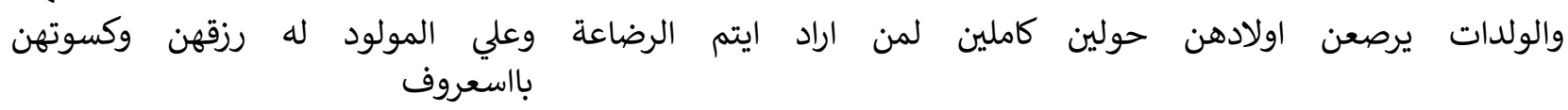

"The mothers shall give suck to their children for two whole years

(that is) for those (parent) who desire to complete the term of sucking, but the father of the child shall bear the cost of mother's food and clothing on a reasonable basis Q2:333"

It is pertinent to know that the development of any society is said to be sustained only if the development of today will not negatively affect the development of the future generation. Therefore, if sustainable goal of 2030 need to be achieved, adequate measure to reduce mother-child mortality must be taken through provision of effective and effectual health care for the mother and child as well, adequate and sufficient nutrition must be provided for the mother and the child.

Over the years several efforts and approaches have been made to tackle mother/child mortality rate, mal-nutrition, reduction of hunger most especially among the mothers and infant babies. Yet, the problem is still lingering up to today in the country. Moreso, several campaigns have been made on breast feeding particularly on exclusive breast feeding and family planning by different experts in the health sector and different organizations with less attention on the religious aspect of it. It is on this note that this study through descriptive analysis intends to focus on perspective of Islam on child weaning and breast feeding. The paper therefore discovered that breast feeding based on the recommendations of Quran and Sunnah is very advantageous and beneficial to the mother and child, as it gives the mother enough room to rest from stress of the labour and allow her body system to recover from the pains of the labour. Therefore, the breast feeding period will bring about gap between the baby and incoming one which will allow full concentration on the baby at hand, reduces excessive spending on baby formula, saves the mother from likely future diseases like diabetes, blood pressure, cancer, cardiovascular disease and the likes since its saves the babies from future diseases such as type 2 diabetes, obesity and others.

\section{Conceptualizing Sustainable Development}

Sustainable development comes from two words "sustain" and "development" sustain according to Hornby is to provide enough need in order to live or exist and to make something continue for some time, while development means gradual growth of something so that it become more advanced or stronger. Sustainable Development therefore refers to development that is sustained and last long. For any society /nation to have a sustained development, the following needs are to be met;

a. Uninterrupted power supply

b. Adequate supply of drinkable water in every nook and craning of

the society

c. Provision of good motor-able road

d. Provision of well maintain and lasting railways

e. Provision of good air ways compare to other developed countries

of the world

f. Uninterrupted food supply 
INTERNATIONAL JOURNAL OF ACADEMIC RESEARCH IN BUSINESS AND SOCIAL SCIENCES

Vol. 8, No. 7, July 2018, E-ISSN: 2222-6990 @ 2018 HRMARS

g. Creation of empowerment and equal employment opportunity for every youth irrespective of gender.

h. Well secure and stable monetary system

i. Creation of avenue for neat and enviable politics

j. Provision of effective and effectual health care services

I. Provision of meaningful and result-oriented education opportunities of all kind for all citizen

m. Creation of well secure environment free from pollution, internal crisis and external aggression

n. Promotion of justice and strong institution

o. Maintenance of international relation and partnership around the world (Adelowo E.D 2009 p:9 and United Nations, 2016 p: 3-4).

Any nation that is able to provide all the above to her citizens, it is said to be developed nation and the sustainability of such services depend on how long is able to keep on making her citizens living conveniently and progressing without hindering the younger generation's development and progress. It is on this basis that the united nation on $25^{\text {th }}$ September 2015 came up with 17 goals agenda to be achieved within the next 15 years in New York. This agenda are the extension of the millennium developed goals (MDGs) and it is those agenda that is now referred to as the Sustainable Development Goals. The whole world is moving towards making every individual creature of the world to live conveniently and interact with each other without negative impact on each other. The said goals among others are:

a. To end poverty in all forms everywhere in the world by 2030

b. To end hunger, achieved food security and improve nutrition and promote sustainable Agriculture

c. To ensure healthy lives and promote well-being for all at all age (International Institute for Sustainable Development, 2016).

\section{Conceptualizing Breastfeeding and Weaning}

Breast feed is an age long custom among human race. It is suckling of the breast by the child or giving offspring breast by the mother. It is required process between age 0 month and 2 years as mentioned in the Qur'an

$$
\text { والوالدات يرضعن اولادهن حولين كاملين لمن ارادان يتم الرضاعة }
$$

"The mother shall give suck to their offspring for two whole years if (the father desire to complete the term) Q2:233

Breastfeeding in this regard is giving of breast milk to the offspring male or female. Exclusive breast milk is required for the first six months, after which it can be supplemented with other feeds until the Child reach the age of two giving of breast by the (real) mother is better and most preferable than any other means ( sheheda 2016). Breast feeding period for a nursing mother is complete two years without addition and it is the responsibility of the father to bear the finance in term of feeding and clothing the nursing mother.

From the Jurist point of view it is the reaching of human milk from the throat to the abdomen of the child without exceeding two years (24 months) Hanafi School are differ on the periodization of breastfeeding but the first group is Abu Hanifah and others who believe that the period of breastfeeding is two and a half years that is to say thirty (30) months while the second group are those who asserted that breastfeeding is two years only (2000 P: 225-226) 
INTERNATIONAL JOURNAL OF ACADEMIC RESEARCH IN BUSINESS AND SOCIAL SCIENCES Vol. 8, No. 7, July 2018, E-ISSN: 2222-6990 @ 2018 HRMARS

They based their argument on the on Qur'an 46:14

$$
\text { وحمله وفصاله ثلاثين شهرا }
$$

"The carrying of the (child) to his weaning is (a period of) thirty months"

They argued that the least period of pregnancy is six months and the remaining twenty four months is for breastfeeding. They uphold the view that Ali bin Abitalib (may Allah confer honor upon him) interpretation of the above verse to Uthman bin Affan (may Allah be pleased with him) is that it is possible for a woman to give birth at the sixth month of pregnancy then the remaining two years is for breastfeeding. Therefore, if the least period of pregnancy is six months then the remaining two month is for breast feeding. Meanwhile, Imam Hanafi and his group held the view that maximum duration for pregnancy is two and a half years (thirty months) and maximum duration for breastfeeding is two and a half years (thirty months). On the part of Maliki School breastfeeding is two years two months (twenty six months) (Al-Jisiri 2000 P: 225-226). In contemporary society, this assertion may not be so because of technological advancement for the fact that when the child has reached the final stage of growth around twenty four to twenty eight weeks (six to seven months) a complete person has fully formed only it need to grow and develop because the body system of such fetus has not fully resume to functioning meaning that the possibility of its survival is low but not withstanding as those group that say; the least period of staying of the fetus in the womb is six months and the remaining twenty four months is for breast feeding. Meanwhile if it is nine months then above verse 14 of Qur'an 46 may not be suitable for them. However, Qur'an 2 verse 233quoted above may be based on their argument. On the part of Abu Hanifa who propose two and a half years of pregnancy that may not work in contemporary society as rightly mentioned above due to the fact that a pregnant within nine to eleven months which is consider as normal and maximum duration of pregnancy in present days can be easily removed from mother's womb either through inducement or surgical operation, therefore in this direction one may go with those who says breastfeeding of a baby is complete two years on a normal delivery or premature delivery based on Qur'an 23:12-14

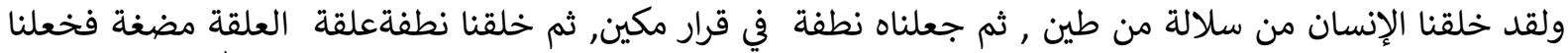



"And indeed We created man (Adam) out of extract of clay (water and earth)"

"Thereafter We made him (the offspring of Adam) as a Nutfah (mixed drop of male and female sexual discharge and lodged it) in a safe lodging (womb of the woman)"

"Then We made the Nutfah into a clot (a piece of thick coagulated blood) then We made the clot into a little lump of flesh, then We made out of that little lump of flesh bone, then We clothed the bone with flesh and then We brought it forth as another creation. So Blessed is Allah, the Best of creators"

Also Qur'an 31:14 has this to say

$$
\text { حملته أمه وهنا علي وهن وفصبه في عامين أن اشكرلي ولوالديك إلي المصير }
$$

"His mother bore him in weakness and hardship upon weakness and hardship and his weaning is in two years give thanks to Me and to your parents. To me is the final destination"

In this regard Al-Zamkhashari (2005) observed that if the least duration of pregnancy is six months then the period of breast feeding is complete two years based on the Qur'an 2:233

"Complete two years"

$$
\text { حولين كاملين }
$$


INTERNATIONAL JOURNAL OF ACADEMIC RESEARCH IN BUSINESS AND SOCIAL SCIENCES

Vol. 8, No. 7, July 2018, E-ISSN: 2222-6990 @ 2018 HRMARS

However based on the above quoted verses breastfeeding is a complete two years based on the Hadith

عن عبد الله بن عباس, أنه كان يقول: ما كان في الحولين وإن كان مصة واحدة فهو يحرم

narrated by Abdullahi ibn Abas that:he (Prophet Muhammad (S.A.W) is saying whatever within two years even if it is a suckling it prohibit (whatever blood relation prohibited)

(Mu'ata Malik : 1285)

and Abdullah ibn Mashood also has this says

$$
\text { لا رضاعة إلا ماكان في الحولين }
$$

"there is no breastfeeding except what is within two years" (Mu'ata Malik : 1512)

Qur'an 31:14 also says

$$
\text { حملته أمه وهنا علي وهن وفصبه في عامين }
$$

"His Mother bore him strain by strain; his nursing (suckling) period lasted for two years"

Weaning is a gradual process of transferring from exclusive breastfeeding (breast milk) of the baby to daily diet (food, vegetable, fruit and animals). The general guideline of the Qur'an for weaning of a child is maximum of two years based on the Qur'an 31 verse 14 quoted above. It may be before the end of the two years mentioned due to Qur'an 2:233

$$
\text { لمن اراد أن يتم الرضاعة }
$$

"If the (father) desire to complete the term"

The implication of this is that it is permissible to breastfeed in less than two years based on the father's decision and mutual consent of both parent based on Qur'an 2:233 that says;

$$
\text { فإن اراد فصالا عن تراض منهماوتشاور }
$$

"if the (both) decide on weaning by mutual consent and after due

consultation"

The mutual consent is to agree upon when to wean the baby and the state or health condition of the baby as required to weaning. This agreement and decision may go beyond the child's health, it may extend to the readiness of the mother to bear another child or not, it may also require consultation and seeking advice from expert (Obstetric/gynecologist) especially when the mother used to give birth through surgical operation. The process of breastfeeding and weaning lies between the father and the mother but the father shoulder the financial responsibilities as rightly mentioned in the Qur'an 2:33

$$
\text { وعلي الموالد له رزقهن وكسوتهن بالمعروف }
$$

"but the father of the child shall bear the cost of the mother's food and clothing on a reasonable basis"

In respect of the above verses the father shoulders the following responsibilities during breastfeeding and weaning;

\section{a. Moral and financial support}

To give moral and financial support to the mother, this would serve as motivation and encouragement to the mother for proper breastfeeding and willingness to bear more children. When a mother is adequately financed and support morally through mutual respect and expression of feeling and love on the part of the father, definitely she will not ascertain fear in carrying pregnancy. This is the direction the Qur'an 65:6-7 is heading to when it says

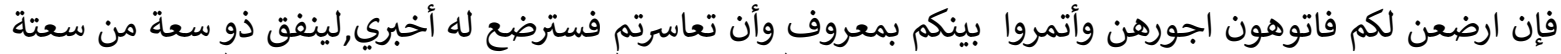

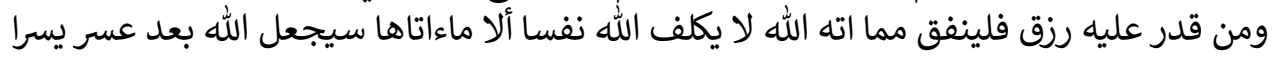


INTERNATIONAL JOURNAL OF ACADEMIC RESEARCH IN BUSINESS AND SOCIAL SCIENCES

Vol. 8, No. 7, July 2018, E-ISSN: 2222-6990 @ 2018 HRMARS

"Then if they give suck to the children, for you give them their due payment and let each of you accept the advice of other in just way. But if you make difficulties for one another then some other women may give suck for him (the father of the child)"

Let the rich man spend according to his means and the man whose resources are restricted, let him spend according to what Allah has given to him, Allah puts no burden on any person beyond what He has given him, Allah will grant after hardship ease"

\section{b. Food and clothing}

It is the responsibility of the father to feed and clothe the nursing mother, this would improve her health, good diet will improve the mother's health as well as that of the child because if a nursing mother take a good and complete diet, it would reflect in her milk in which the child is suckling and this would also affect the baby's growth and development. As well the neatness of the mother will also improve the health of the child. However, a situation the nursing mother lacks adequate nourishment and neatness the child may likely suffer kwashiorkor and other communicable diseases that may arise from malnutrition and dirtiness.

\section{c. Maintenance of the child's need and care}

It is the responsibility of the father to finance the health care of the child if the child is sick as well as paying for the child clothing and other related care and education according to Qur'an 65:7 quoted above. In the same vein should the child die along the process of nursing, it is the responsibility of the father to pay the cost of maintenance.

\section{d. Decision Making}

It is the responsibility of the father to decide on the weaning of the child but he shall sought the consent of the mother when taking such decision as mentioned in Qur'an 2:33 quoted above.

\section{The Implication of Breastfeeding and Weaning on Sustainable Development by 2030}

Breastfeeding for the period of full two years as mentioned in the Qur'an is no doubt provides the child with a long term benefit, it protect the child from ear infection and other allergies, it establish foundation of love and sharing of bound of love and attraction between the mother and the child. It also increases the child intelligent quotient (IQ) and such children are well emotionally adjusted. It is not surprising that the World Health Organization (WHO) and United Nations Children's Fund (UNICEF) are stressing the importance of breastfeeding for period of two years most especially in the third world countries. It is hope as UN prediction to save 2,000 million dollars annually that is badly needed for health and education (Muhammed, 2017) If such amount is saved it can be used for other developmental project which will make those countries develop.

It is believed that human milk contain nutrients with which the child grow and develop faster, these nutrients are released in proportion which is sustainable for its body to digest and absorb, these nutrient element are changed on daily basis according to the need of the baby. Every child either normal child of 28 weeks and above or 24 weeks (pre mature) baby has special formula prepared in the mother's breast to make it suitable diet for them by Allah in His mercy upon mankind in line with this Qur'an 82:7-8 that says:

$$
\text { الذي حلقك فسونك فعدك بي اي صورة ماشاء ركبك }
$$


INTERNATIONAL JOURNAL OF ACADEMIC RESEARCH IN BUSINESS AND SOCIAL SCIENCES Vol. 8, No. 7, July 2018, E-ISSN: 2222-6990 @ 2018 HRMARS

"Him who created thee, fashion thee a just bias. In whatever form He wills. Does He put thee together"

When a child is adequately nourished through the mother, such child will grow and develop properly and as well be immunized against infection and this will definitely reduce the child mortality. This is more reason why World Health Organization (WHO) currently recommends two years breastfeeding for child. It is also believed that child who is not breastfeed is prone to risk of common condition such as acute otitis media, gastro enteritis, dermatitis and life threatening condition like severe lower respiratory infections and other diseases resulting to infant death [16]. More so, such children are likely to have high blood pressure, increased risk of type 2 diabetes, risk of obesity and other lower score on intelligence tests in later life. Other associated risk to child who is not well breastfed includes type 1 diabetes, asthma and child leukemia. However, a child who is well breastfed for two complete years particularly those that are exclusively breastfed for the first six months are protected against gastro intestinal tract and respiratory tract infection as well as otitis media and pneumonia. On the part of the mother, mother who breastfeed less than two year is likely not to free from the risk of type 2 diabetes, breast cancer, ovarian cancer, and hypertension as well as cardio vascular diseases as noted by America Academy of Family Physicians (AAFP),20017).

In the same direction, women who breastfeed for two years have enough time to rest and for her body system to settle from the previous pain and stress and as well to give gap between the baby and the incoming one; this will give room for the family planning for the future of their offspring.

\section{Conclusion and Recommendations}

In line with the above, it is concluded that if Muslims strictly follow the Qur'anic injunction on breastfeeding and weaning of a child, this would increase both the health of the Mother and the child as well as ensuring proper planning of the family, as these will reduces mother/child mortality rate. It is in this direction the following were put forward for recommendation;

That woman should breastfeed for two years as mention in the Qur'an

That father should bear the care and maintenance of both the mother and the child during the process of breastfeeding and weaning despite the fact that the care of the family rest upon the father. That both parents should jointly make decision on mutual consent when it comes to weaning of the child, this will assist in creating love and sense of belonging within the family.

That the child weaning should be gradual process this will help the Child to adapt to newly introduce foods easily

That both parent should sought the advice of expert (Obstetric/Gynecologist) when it comes to child weaning most especially when it involve carrying new pregnancy.

\section{References}

Adelowo, E.D. (2009). Religion and Sustainable Development in Adesewo M.A, Falako F.O and Adebayo R.I Religion and Sustainable Development National association for the Study of Religious and Education (NASRED) Journal Ilorin publisher National association for the Study of Religious and Education (NASRED)

Al-Jiziri (2000) FiqhAlaMadhahib Al-Arbah Cairo Dar Al-Fajr Publication

America Academy of Family Physicians (AAFP), (2017) Breastfeeding, Family Planning Supporting

Az-Zamkhashari (2005) TafsirbAl-kashaf Beirut Lebanon Dar Al-Ma'arifah Pubication p: 135

Hornby (2011). Oxford Advance Learner's Dictionary International Student's Edition $8^{\text {th }}$ Edition New York Oxford University press 
INTERNATIONAL JOURNAL OF ACADEMIC RESEARCH IN BUSINESS AND SOCIAL SCIENCES

Vol. 8, No. 7, July 2018, E-ISSN: 2222-6990 (C) 2018 HRMARS

International Institute for Sustainable Development (IISD), (2016) Comparing the MDGs and SDGs

http://li.www.iisd.org/topic/sustainable-development retrieved 04 June 2017.

Muhammad, A. A (2017) Breastfeeding and Islamic teaching

http://www/islamicgarden.com/article1025.html/ retrieved 04 June 2017

Sayuti, A. (1996) Mu'ata' Al-Imam Malik Riwayah bn Yahaya Al-Laithy Beirut Lebanon Iqra printing and Publication

Shaheda, Y. (2016). Islamic and Cultural Practice in Breastfeeding.

http://leadertoday.breastfeedingtoday-Ili.org/islamic-and-cultural-spractice-inbreastfeeding/ retieved 04 June 2017

United Nation (2016), The Sustainable Development Goals Report, http://unstates.org/unsd/statecom/47th.session/documents/2016-2-1AEG.SDGsrevl-E.pdf (retrieved 04 June 2017) 